\title{
The Grand Coalition in West Germany and Great Britain's Second Application to Join the European Communities, 1966-1969
}

\author{
Henning TÜRK
}

Researchers have subjected Great Britain's second application to join the European Communities to intense scrutiny in recent years. They primarily have focussed on British and French attitudes. ${ }^{1}$ In contrast, relatively little attention has been paid to West Germany's stance. Existing studies tend to examine the latter's role in bilateral contexts. ${ }^{2}$ Here, the West German government is generally characterized as an 'honest broker'; it is claimed to have mediated between the pro-British Benelux countries and Italy on the one hand and a still rejectionist France on the other. However, this view of things entails two difficulties. First, it means the uncritical adoption of the German government's self-labelling, without scrutinizing how seriously it pursued its supposed role as a broker. ${ }^{3}$ Second, it gives rise to a monolithic perception of Germany's attitude. The conceptual frameworks typical of the ministries with most influence over European policy differed; their interests and strategies thus did so as well. Yet these differences have been smoothed over. In what follows, I therefore attempt to provide a more nuanced view of the German government's approach. What was the stance of the grand coalition government

1. See, for example, W. LOTH (ed.), Crises and Compromises. The European Project 1963-1969, Nomos, Baden-Baden, 2001; O.J. DADDOW (ed.), Harold Wilson and European Integration. Britain's Second Application to Join the EEC, Frank Cass, London, 2003; F. KNIPPING, M. SCHÖNWALD (eds.), Aufbruch zum Europa der zweiten Generation. Die europäische Einigung 1969-1984, Wissenschaftlicher Verlag Trier, Trier, 2004. For a broader approach see N.P. LUDLOW: The European Community and the Crises of the 1960s. Negotiating the Gaullist challenge, Routledge, London/New York, 2006, pp.133-198.

2. K. BÖHMER, 'We too mean business'. Germany and the second British application to the EEC, in: O.J. DADDOW, op.cit., pp.211-226; H. PHILIPPE, 'The Germans hold the key'. Britain's second application to the European Community and the hope for German help, in: C. HAASE (ed.), The Public and British Foreign Policy since 1867, Philo, Berlin/Wien, 2003, pp.153-182; C. GERMOND, The 'recalcitrant partner' and the 'honest broker'. France, Germany and Britain's second application to the EEC, 1966-1969, unpublished paper for the XVI. International Economic History Congress in Helsinki, August 2006, http://www.helsinki.fi/iehc2006/papers3/Germond.pdf; G. WILLE, 'Which Europe? Quelle Europe? Welches Europa?'. British, French and German Conceptions of Europe and Britain's Second Attempt to Join the EEC, in: K. RÜCKER, L. WARZOULET (eds.), Quelle(s) Europe(s)? Which Europe(s)? Nouvelles approches en histoire de l'intégration européenne, P.I.E.-Peter Lang, Bruxelles et al., 2006, pp.225-237 deals mainly with the West German government's attempt to prevent an EEC crisis.

3. Kiesinger had already referred to the West German government as an 'honest broker' in talks with the British prime minister Harold Wilson on 16 February 1967. See Gespräch des Bundeskanzlers Kiesinger mit Premierminister Wilson, 16.2.1967, in: Akten zur Auswärtigen Politik der Bundesrepublik Deutschland [AAPD] 1967, Institut für Zeitgeschichte (ed.), Oldenbourg, München, 1998, Doc.57, pp.284-291, here p.288. Compare W. BRANDT, Begegnungen und Einsichten. Die Jahre 1960-1975, Hoffmann und Campe, Hamburg, 1976, p. 205. 
between 1966 and 1969? How much influence did the individual ministries have and how did they view the possibility of Britain joining? Our investigation of these matters will also furnish us with a key to understand the European policies pursued by the grand coalition. ${ }^{4}$

A broad range of sources can help us answer these questions. Internal memoranda produced by the Foreign ministry, the ministry of economics and the federal chancellery are the key instruments used for determining how Britain's membership application was assessed and which objectives were formulated on this basis. These evaluations and goals were incorporated into the formulation of the West German government's overall strategy. The process of agreement necessary to achieve this strategy can be delineated on the basis of notes, correspondence and the minutes of cabinet meetings and of the committee of permanent secretaries on European issues. ${ }^{5}$ How this strategy was implemented is examined with the aid of the minutes of bilateral talks and multilateral negotiations. Of course, the West German government used the new insights into the stance of the other countries gained from these talks to revise its own strategy. ${ }^{6}$

\section{Bilateral Exploratory Talks and Political Cooperation Between the Six (December 1966-May 1967)}

By the time the government of chancellor Ludwig Erhard (CDU) fell apart in October 1966 it had become clear that the foreign policy pursued in the preceding years, closely attuned to American interests, had failed to strengthen West Germany's position within the international system. Under Erhard, cracks appeared in the pillars of German foreign policy erected by chancellor Konrad Adenauer (CDU). Germany's relations with its closest allies, the US and France, had reached a low point. The EEC and NATO, central to West Germany's hopes of returning to the international stage, lurched from one crisis to the next.

In this context, the CDU/CSU parliamentary group's nomination of Kurt Georg Kiesinger, the 'Ministerpräsident' of Baden-Württemberg, as candidate for chancellor, on 10 November 1966, appeared as a signal for the new government's willingness to adopt a new foreign policy course. Kiesinger was considered to be a supporter of the Franco-German rapprochement, which he had promoted

4. See H. TÜRK, Die Europapolitik der Großen Koalition 1966-1969, Oldenbourg, München, 2006.

5. The committee of permanent secretaries on European issues brought together the permanent secretaries from the Foreign ministry, the ministry of Economic affairs, the ministry of Finance and of Agriculture to coordinate German European policy. See C. GERMOND, H. TÜRK, Der Staatssekretärausschuss für Europafragen und die Gestaltung der deutschen Europapolitik 1963-1969, in: Zeitschrift für Staats- und Europawissenschaften, 2(2004), pp.56-81.

6. The author would like to thank Alex Skinner for the translation of this article. 
vigorously since 1963, as the West German government's representative with responsibility for cultural affairs within the framework of the Franco-German Treaty. ${ }^{7}$ The SPD also made it clear, before the coalition negotiations, that it was particularly keen to improve Franco-German relations. ${ }^{8}$

In parallel with these developments in West Germany, which would determine the future course of its foreign policy, the British government announced its intention to join the European Communities (EC) in the House of Commons on 10 November. ${ }^{9}$ The possibility of British accession was therefore discussed when the coalition negotiations between the CDU/CSU and SPD began in Bonn on 14 November 1966. The negotiators agreed to back British membership. At the same time, as could be expected, both delegations spoke in favour of deepening Franco-German relations. The aim was thus to facilitate Britain's entry only in tandem with Paris. ${ }^{10}$

The difficulty of this project became apparent the first time the members of the grand coalition made contact with their French colleagues. In talks with Foreign minister Willy Brandt (SPD) on 15 December 1966 the French president Charles de Gaulle made no secret of his still negative attitude towards British membership. ${ }^{11}$ As the first priority of the grand coalition was to patch up the fissures in the Franco-German relationship, on the basis of which it hoped France would support its plans for a more pro-active Ostpolitik, it acted with extreme caution. Moreover, when de Gaulle threatened with serious consequences should the West German government take on the role of a champion of British interests, the grand coalition followed the French recommendation to put the issue of accession in the bilateral talks initially on the back burner, until Britain's intentions had become clearer. ${ }^{12}$

However, the West German government didn't get very far with its tactics of playing and waiting game. When British prime minister Harold Wilson visited Bonn on 15-16 February 1967, it was already apparent that Great Britain was

7. A. BAUMANN, Kurt Georg Kiesinger - Ein Freund Frankreichs?, in: Historisch-Politische Mitteilungen, 10(2003), pp.225-253; P. GASSERT, Kurt Georg Kiesinger 1904-1988. Kanzler zwischen den Zeiten, Deutsche Verlags-Anstalt, München, 2006, pp.462-468.

8. Acht-Punkte-Programm der SPD vom 2. November 1966, in: Die SPD-Fraktion im Deutschen Bundestag, Sitzungsprotokolle 1961-1966, 2. Halbband, Droste, Düsseldorf, 1993, p.1000, footnote 7.

9. British Information Nr.587/11.11.1966, in: Bundesarchiv Koblenz [BaK], B102 (Bundesministerium für Wirtschaft), vol.61702.

10. 'Aus den Notizen von den Diskussionen der Verhandlungskommission der SPD mit den Verhandlungskommissionen der CDU/CSU und FDP', hier: Gespräch am 15.11.1966, pp.4 f., Archiv der sozialen Demokratie [AdsD], Bestand Helmut Schmidt, vol.5077; 'Aktenvermerk über die Besprechung mit der SPD am 15.11.66’, BaK, Bestand Rainer Barzel, vol.354, pp.37-48.

11. Gespräch des Bundesministers Brandt mit Staatspräsident de Gaulle in Paris, 15.12.1966, AAPD 1966, Doc. 398, pp.1637-1646.

12. Drahtbericht des Gesandten Peter Limbourg aus Paris, 09.01.1967, Politisches Archiv des Auswärtigen Amts [PAAA], B150, vol.94, pp.182 f.; Gespräch des Bundesministers Brandt mit dem französischen Außenminister Couve de Murville, 13.01.1967, AAPD 1967, Doc.15, pp.78-89, here p.89; Gespräch des Bundeskanzlers Kiesinger mit Staatspräsident de Gaulle in Paris, 13.01.1967, AAPD 1967, Doc.16, pp.90-94. 
determined to accede to the Communities. Wilson pressed chancellor Kiesinger to put in a good word for Britain when talking to the French. This prompted Kiesinger to explain that careful dialogue with the French government was the only route to success. ${ }^{13}$ Foreign minister Brandt advised the British to continue preparing their application to join on a bilateral basis and to refrain from beginning multilateral negotiations at this stage. ${ }^{14}$

This strategy of deferment, however, was underpinned by dissimilar motives at the Foreign ministry and the federal chancellery. The Foreign ministry supported British membership for political and economic reasons. Among other things, it expected British accession to stimulate German exports, boost technological cooperation and make Western Europe less dependent on the United States. ${ }^{15}$ However, the Foreign ministry regarded an early application for membership as dangerous: Britain's ongoing economic problems would provide France with numerous arguments for rejecting it. ${ }^{16}$ Chancellor Kiesinger and his pro-French entourage at the federal chancellery, meanwhile, were convinced that British membership would hinder the EEC developing into a political union with a common foreign policy. ${ }^{17}$ Kiesinger feared that the EEC would become an 'economic monster without the capacity to take political action'. ${ }^{18}$ The attention of the federal chancellery thus focussed primarily on initiating political cooperation among the Six before Britain's accession.

The summit conference of the six EEC countries organized on the occasion of the tenth anniversary of the Treaties of Rome in May 1967 offered a good opportunity to ensure that political cooperation got off the ground. The differing priorities of the federal chancellery and the Foreign ministry became particularly apparent in the preparations for this summit conference. In April 1967 the parliamentary statesecretary in the chancellery, Karl Theodor Freiherr von und zu Guttenberg, reported to Kiesinger that the Foreign ministry wished the possibility of British accession to take centre stage at the summit conference. For the chancellery, meanwhile, getting political cooperation up and running was top priority. ${ }^{19}$ At the summit conference in Rome, Kiesinger then spoke in favour of

13. Gespräch des Bundeskanzlers Kiesinger mit Premierminister Wilson, 15.02.1967, AAPD 1967, Doc.55, pp.271-282, here p.276.

14. Gespräch des Bundeskanzlers Kiesinger mit Premierminister Wilson, 16.02.1967, AAPD 1967, Doc.57, pp.284-291, here p.289.

15. Aufzeichnung StS 105/67 von Staatssekretär Lahr betr. Beitritt Großbritanniens zur EWG, 11.01.1967, PAAA, B2, vol.130.

16. Aufzeichnung der Abteilung I des Auswärtigen Amts betr. Großbritannien-EWG, 03.03.1967, PAAA, B150, vol.98, p.2127; Runderlass des Staatssekretärs Lahr betr. Beitrittsantrag Großbritanniens zur EWG, 15.03.1967, PAAA, B150, vol.99, pp.2564 f.

17. Gespräch des Bundeskanzlers Kiesinger mit dem britischen Botschafter Frank Roberts am 9. Februar 1967, 10.02.1967, Archiv der Christlich-Demokratischen Politik [ACDP], Nachlass Kiesinger, vol.287; Sitzung des CDU-Bundesvorstands am 13. Februar 1967, in: Kiesinger: 'Wir leben in einer veränderten Welt' Die Protokolle des CDU-Bundesvorstands 1965-1969, bearb. von G. BUCHSTAB, Droste, Düsseldorf, 2005, Doc.11, pp.420-479, here p.440.

18. Vermerk des Parlamentarischen Staatssekretärs im Bundeskanzleramt, Guttenberg, 22.05.1967, BaK, Nachlass Guttenberg, vol.154, pp.150-154, here p.152 
political cooperation among the six EEC countries, alluding to the escalating crisis in the Middle East. To this end, he suggested further meetings of the heads of state and government or Foreign ministers, which should be prepared by experts. When this proposal was rejected, most notably by the Netherlands, which pointed out that Great Britain would not be taking part, Kiesinger offered to start off the cooperation between the Six, but to remain open to the participation of others. ${ }^{20}$ After the meeting was temporarily adjourned, it was very cautiously agreed that the Foreign ministers would examine how the six EEC countries 'could gradually develop closer political ties'. ${ }^{21}$ A further meeting of the heads of state and government was planned for 1967 but failed to materialize.

It had thus become clear that it would be almost impossible to begin political cooperation given the current state of the European Communities. As a result, parliamentary secretary Guttenberg referred bitterly to Dutch Foreign minister Joseph Luns:

'It makes you wonder why this man received the Karlspreis. Those who hinder the possible in favour of the desirable are slowing down the unification of Europe, instead of promoting it'.22

In a confidential briefing, government spokesman Karl-Günther von Hase, who was close to Kiesinger, went so far as to characterize the Dutch attitude at the summit conference in Rome as 'crude' and accused them of pursuing 'bulldozer politics'. The role of the Dutch with respect to the question of British membership was that of a 'Trojan ass'. ${ }^{23}$ Rolf Lahr, permanent secretary at the foreign ministry, struck a different note in his description of the summit conference. He stated that the 'main topic', British membership, was not discussed at all. Everyone paid tribute to de Gaulle, though "no-one dealt the Europe celebrated on that day a heavier blow than he did'. ${ }^{4}$

\section{Crisis management (June 1967-December 1967)}

After the European Communities had officially received the accession applications of Great Britain, Denmark, Norway and Ireland on 11 May 1967, the Council of ministers agreed on 27 June to request that the Commission produce a report on their applications. ${ }^{25}$ This provided a breathing space, which the federal chancellery

19. Vermerk Guttenbergs betr. Gespräche des Herrn Bundeskanzlers, 23.04.1967, BaK, Nachlass Guttenberg, vol.90, pp.258-260, here p.258.

20. For an account of how the summit conference unfolded, see Staatssekretär Lahr, z. Zt. Rom, an das Auswärtige Amt, 31.05.1967, AAPD 1967, Doc.197, pp.842-848.

21. Kommuniqué über die Konferenz der Staats- und Regierungschefs der Mitgliedsstaaten der EWG am 29. und 30.05.1967 in Rom, in: Europa-Archiv, 22(1967), pp.D268 f., here p.D269.

22. K.T. ZU GUTTENBERG, Fußnoten, Seewald, Stuttgart, 1972, pp.129 f.

23. Drahtbericht Nr.173 des Botschafters Knoke, Den Haag, 06.06.1967, PAAA, B150, vol.104, pp.4513 f., here p.4513.

24. R. LAHR, Zeuge von Fall und Aufstieg. Private Briefe 1934-1974, Knaus, Hamburg, 1981, p.468. 
in particular used to deepen Franco-German relations. On 15 June, parliamentary secretary at the chancellery Guttenberg thus explained to the French ambassador François Seydoux that 'the likely expansion of the EEC [makes] an intensification of Franco-German cooperation all the more important' ${ }^{26}$ At the Franco-German summit on 12-13 July in Bonn, a large number of reforms were decided upon, particularly with respect to institutions. ${ }^{27}$ De Gaulle and Kiesinger also agreed on how to proceed on the issue of accession. Both spoke in favour of a thorough investigation of the problem of accession by the Council of ministers following submission of the Commission's report. However, how long this investigation stage should last was not one of the topics discussed. ${ }^{28}$

The Commission then provided new material for the debate on 29 September in its comments on the membership applications. It recommended starting negotiations with the accession candidates in order to examine in depth and resolve together the economic and political problems thrown up by accession. The Commission underlined that the process of enlargement must not stop the Communities from developing into an economic union. ${ }^{29}$

The ministry of economic affairs took the same view, particularly on the last point. On 4 July 1967, in a letter to chancellor Kiesinger, Karl Schiller (SPD), minister for economic affairs, made a spirited contribution to the government's efforts to determine its stance on these issues. Schiller sent Kiesinger a memorandum written by his permanent secretary Fritz Neef on the economic implications of British membership. Neef underlined the risks involved for the energy sector. For a number of reasons, British coal was cheaper than coal from Germany. If Britain joined and the current trade barriers were removed thereupon, the process of adjustment in the German coal industry would become even more difficult. ${ }^{30}$ It was therefore crucial that before the access of British imports the Common market had reached a sufficiently advanced stage. Moreover, Neef

25. Bundesminister Brandt an die Botschaft London, 27.06.1967, AAPD 1967, Doc.236, pp.963 f.

26. Vermerk über den Besuch des Botschafters Seydoux am 15.06.1967, BaK, Nachlass Guttenberg, vol.154, pp.155 f., here p.155.

27. All these measures were mentioned in an exchange of letters between the two Foreign ministers in October. See Foreign minister Brandt's talks with his French counterpart Couve de Murville in Paris, 17.10.1967, AAPD 1967, Doc.355, pp.1393-1404.

28. Gespräch des Bundeskanzlers Kiesinger mit Staatspräsident de Gaulle in Bonn, 12.07.1967, AAPD 1967, Doc.261, pp.1035-1047, here p.1037; Gespräch des Bundeskanzlers Kiesinger mit Staatspräsident de Gaulle in Bonn, 13.07.1967, AAPD 1967, Doc.263, pp.1052-1062, here pp. $1058 \mathrm{f}$.

29. Stellungnahme der Kommission der Europäischen Gemeinschaften an den Rat vom 29.09.1967 betr. Beitrittsgesuche Großbritanniens, Irlands, Dänemarks und Norwegens (Auszüge), in: Europa-Archiv, 22(1967), pp.D481-D499, here pp.D498 f.

30. In the mid-1960s, German coal was no longer internationally competitive. In addition, it was increasingly squeezed out as a source of energy by cheaper crude oil. This led to numerous job losses and major unrest, particularly in the Ruhr. The grand coalition government thus saw as one of its key tasks to work out a sustainable solution for German coal production. For more on this issue, see C. NONN, Die Ruhrbergbaukrise. Entindustrialisierung und Politik 1958-1969, Vandenhoeck\&Ruprecht, Göttingen, 2001. 
emphasized that the generally positive appraisal of the prospects for the German economy was based on the key assumption that the EEC's evolution towards a common market would not be hindered by accession negotiations. Achievements must not be put at risk again; institutional cooperation in particular must remain in place. The ministry of economic affairs considered the fusion of the three treaties of Rome into one single treaty on the European Community as a possible solution to these problems. The foundations for this had already been laid through the fusion of the executives of the European Communities on 1 July $1967 .{ }^{31}$ The ministry of economic affairs recommended beginning negotiations on accession and in parallel within the Communities negotiating the merger of the treaties. The result would be British accession to an amalgamated Community. ${ }^{32}$

During the following weeks, this strategy was discussed at interministerial level within the West German government. It was agreed that the government would make a statement on the issue of fusion at the meeting of the Council of ministers on 2-3 October. ${ }^{33}$ There, Council president Karl Schiller presented the fusion of the treaties as a task to be completed in parallel with the expansion and internal development of the EEC. ${ }^{34}$ Permanent secretary Lahr subsequently proposed inserting the provisions of the EURATOM and ECSC treaties into the EEC treaty in the form of sections on 'energy policy' and 'technology policy'. This proposal was supported only by the French government. The other governments remained sceptical: they viewed such a fusion as a means of delaying the accession of the applicant states. Finally, the Council of ministers asked the Commission to investigate the problems of fusion. ${ }^{35}$ As a result of the scepticism felt by the other countries and the Commission, which feared that its authority would be curtailed, this report was not drawn up over the next few months despite German pressure. The plan to deepen the Community in parallel by merging the treaties thus fell apart.

In order to avoid the intensification of the dispute between France and the pro-British countries, chancellor Kiesinger set forth a new idea in conversation with ambassador Seydoux on 12 October 1967. Kiesinger pointed out that as the Commission had submitted its report, the problems pointed out would have to be discussed. However, because Great Britain and the Netherlands were pressing for the talks to be resumed quickly, one could perhaps ask the Commission to examine in depth some of the difficulties mentioned in the report. To that end, the

31. On the German role in the merger of the Communities' executives, see H. TÜRK, op.cit., pp.33-45.

32. Aufzeichnung des Staatssekretärs Neef betr. wirtschaftspolitische Überlegungen zum Beitritt Großbritanniens und anderer EFTA-Staaten zu den Europäischen Gemeinschaften, 01.07.1967, BaK, B102, vol.61703; Schiller an Kiesinger, 04.07.1967, PAAA, B20, vol.1167.

33. Ergebnisprotokoll über die Ressortbesprechung vom 6.9.1967 im Auswärtigen Amt zur Frage der Verschmelzung der Europäischen Gemeinschaften, 07.09.1967, PAAA, B20, vol.1768; Niederschrift über die Sitzung der Staatssekretäre für Europafragen am 28.09.1967 im Bundeswirtschaftsministerium, 29.09.1967, BaK, B102, vol.61704.

34. Erklärung des deutschen Bundesministers für Wirtschaft, Karl Schiller, auf der Sitzung des Rats der Europäischen Gemeinschaften in Luxemburg am 02.10.1967, in: Europa-Archiv, 22(1967), pp.D539-541.

35. Auszug aus dem Ratsdokument R/1390 d/67 (PV/CONS/R5) mr, PAAA, B20, vol.1769. 
Commission could listen to third parties without negotiating with them. According to Kiesinger, the Commission would then act as 'a kind of committee of experts, helping clarify matters on behalf of the Council of ministers, before finally reporting back to it' ${ }^{36}$ Kiesinger went on to explain that in this way one could 'hold the Six together, avoid a conflict and at the same time take the French concerns seriously'. ${ }^{37}$ France, however, rejected this proposal.

As a result of France's unwillingness to make a compromise, the West German government, as president of the EEC's Council of ministers and self-appointed mediator, came increasingly under pressure. Kiesinger therefore tried, in conversation with Seydoux on 14 November, to find out whether there remained actually any chance of compromise. The chancellor inquired about the possibility of talks taking place between Commission officials and British experts during the discussions between the Six on the accession problems. When the French ambassador made only evasive, general comments, Kiesinger responded dramatically that he thought it likely that the EEC would be struck by crisis towards the end of the year or at the beginning of the next. How long, he asked, was the discussion of French concerns to go on? The French position was not clear at all. As an alternative to expert talks, Kiesinger suggested starting the negotiations and, first of all, establishing a uniform view among the Six on the various problem areas. ${ }^{38}$

The concern felt by Kiesinger and many members of the West German government that the EEC might be paralyzed by crisis was anchored in both foreign and domestic political considerations. In terms of foreign policy, the West German government was in a highly unstable situation. It was dependent on good relations with its Western partner states and extremely vulnerable in its intra-German policies and Ostpolitik, which were stagnating markedly after an initial positive response. In terms of security policy it depended on the US and NATO, whose future looked far from bright - and now the EEC was in danger of disintegration. This would certainly shake West Germany's foreign policy system. Kiesinger also held this lack of foreign policy prospects responsible for the growing success of the right-wing extremist NPD and the radicalization of young intellectuals in the extra parliamentary opposition. ${ }^{39}$ The head of the planning

36. Gespräch des Bundeskanzlers Kiesinger mit dem französischen Botschafter François Seydoux, 12.10.1967, AAPD 1967, Doc.348, pp.1368-1375, here pp.1372 f. This proposal was based on a suggestion put forward by the EEC Commission. The ministry of economic affairs submitted this proposal to the cabinet meeting on 11 October as an item of business, where it met with general approval. See Runderlass des Auswärtigen Amts betr. Besuch Reys und der drei deutschen Kommissare in Bonn, 19.09.1967, BaK, B102, vol.120015; Aufzeichnung von der Groebens, 23.09.1967, ACDP, Bestand von der Groeben, vol.051/1; Aufzeichnung des Staatssekretärs im Wirtschaftsministerium, Fritz Neef, 'Stichworte für die Kabinettssitzung am 11. Oktober 1967', 10.10.1967, BaK, B126 (Bundesministerium der Finanzen), vol.36406; Schiller an Kiesinger, 19.10.1967, PAAA, B1, vol.332.

37. Gespräch des Bundeskanzlers Kiesinger mit dem französischen Botschafter François Seydoux, 12.10.1967, AAPD 1967, Doc.348, pp.1368-1375, here p.1373.

38. Gespräch des Bundeskanzlers Kiesinger mit dem französischen Botschafter François Seydoux, 14.11.1967, AAPD 1967, Doc.391, pp.1510-1516. 
commission in the Foreign ministry, Günter Diehl, even warned of dangers on the domestic front should the 'role model of Europe' disintegrate. ${ }^{40}$

Despite Kiesinger's vigorous efforts, France stuck to its hard-line approach. In fact, at another press conference on 27 November, de Gaulle rejected more clearly than ever British accession at the present time. According to him it would cause the disintegration of the Community, which was unable to cope with such a monumental task at the time being. De Gaulle also pronounced himself against starting negotiations, but pointed out that alternatively an economic agreement could be reached with the accession candidates. ${ }^{41}$

French attitudes were thus already clearly defined before the crucial meeting of the Council of ministers on 18-19 December. In order to coordinate the approach of the other countries, the five Foreign ministers met without France during the NATO ministerial council meeting, held on 13-14 December in Brussels. The participants agreed to back accession negotiations at the meeting of the EEC Council. France would have to make its point of view clear. The intention was not to discuss proposals in order to reach a compromise at the procedural level. At the end of the coming meeting, those attending were supposed to pin clearly down what had been achieved. Should it prove impossible to reach an agreement, it was to be established that no motion for adjournment had been tabled and thus all the governments could again propose the subject of 'accession' for the next meeting of the Council of ministers. Great Britain was to persist with its application for membership. ${ }^{42}$

The course of the meeting of the Council had thus already been traced out. On 18 December, a debate specifically dealing with the problem of accession took place, and those attending reached their conclusions on the following day. It proved impossible to reach an agreement on opening the accession negotiations as France still continued to disapprove of them. The accession applications, however, remained on the Council's agenda. ${ }^{43}$

39. Gespräch des Bundeskanzlers Kiesinger mit Premierminister Wilson in Bonn, 16.02.1967, AAPD 1967, Doc.57, pp.284-291, here p.285. Between November 1966 and October 1968, the right-wing extremist National Democratic Party of Germany (NPD) was elected to numerous Land parliaments, a development viewed with concern at home and abroad. At the same time, the radicalization of the leftist extra parliamentary opposition (APO), which opposed the grand coalition government, was coming to a head. See K. HILDEBRAND, Von Erhard zur Großen Koalition 1963-1969, DVA, Stuttgart u.a., 1984, pp.352-403.

40. Aufzeichnung des Ministerialdirektors Diehl betr. deutsche Europapolitik, 06.10.1967, AAPD 1967, Doc.340, pp.1332-1341, here p.1341.

41. Pressekonferenz des französischen Staatspräsidenten, Charles de Gaulle, am 27.11.1967 (Auszüge betr. außenpolitische Fragen), in: Europa-Archiv, 22(1967), p.D561.

42. Vermerk des Staatssekretärs Lahr, 14.12.1967, PAAA, B1. vol.332. For an extract see AAPD 1967, p.1611, footnote 10.

43. Botschafter Sachs, Brüssel (EG), an das Auswärtige Amt, 20.12.1967, AAPD 1967, Doc.442, pp.1686-1694. 


\section{Alternative options on the way to accession (January 1968-March 1969)}

\section{III.1 The Franco-German proposal for a 'trade agreement'}

In the period between January 1968 and March 1969, the grand coalition was at pains, above all, to prevent France from becoming isolated and the EEC from stagnating. How high this risk actually was became clear when the Dutch declared that they would take a very cautious approach to core EEC projects such as the further development of technological cooperation and the establishment of European company and patent law in January 1968. In addition, the Italian government wished to block association and trade agreements. ${ }^{44}$ In parallel with these blocking manoeuvres, the Benelux governments proposed a meeting of the Foreign ministers without France on the occasion of the next meeting of the WEU Council of ministers on 29-30 January 1968, to be followed by a meeting with the British Foreign minister. This would provide an opportunity to discuss cooperation outside of the treaties of Rome. These ideas came at an inopportune moment for the West German government, as they entailed the risk of splitting the unity of Europe and possibly bypassing the French. On 10 January 1968, the cabinet thus rejected the notion of cooperation between the supporters of accession and the applicant countries without France. ${ }^{45}$ Over the next few days, the West German government managed to tone down the plans for the WEU meeting. ${ }^{46}$ This, however, made it necessary to offer the supporters of accession some kind of compensation. The West German government therefore took up de Gaulle's proposal to bring about a rapprochement between the applicant countries and the EEC on trade policy. At the insistence of the West German government, France agreed, within the framework of the Franco-German consultations on 15-16 February, to a joint proposal for a 'trade agreement' between the EEC and the applicant countries, which would apply to industrial and agricultural products. ${ }^{47}$ The Foreign ministry wished to bring Great Britain closer to the EEC through this trade agreement. ${ }^{48}$ Kiesinger, meanwhile, talked of a more general formula 'which creates the impression that we have managed to make some progress'. ${ }^{49}$

After the EEC Council of Ministers had asked the West German government to put the proposed agreement in more concrete terms ${ }^{50}$ on 29 February 1968, these differences of opinion became frequently apparent. The Foreign ministry attempted

44. Niederschrift über die Sitzung der Staatssekretäre für Europafragen am 08.01.1968 im Bundesministerium der Finanzen, 06.02.1968, BaK, B102, vol.61705.

45. Protokollentwurf zu Punkt 5 der Tagesordnung der Kabinettssitzung am 10. Januar 1968: Bericht des Bundesministers des Auswärtigen über die Lage in Brüssel nach der Ratstagung am 18./ 19.12.1967, BaK, Nachlass Carstens, vol.586.

46. Drahterlass des Staatssekretärs Lahr betr. WEU-Ministerrat, Zusammenarbeit mit Großbritannien, 20.01.1968, PAAA, B20, vol.1479; Drahtbericht des Botschafters Knoke, Den Haag, an das AA betr. WEU-Ministerrat, Zusammenarbeit mit Großbritannien, 22.01.1968, PAAA, B20, vol.1479; Runderlass des Staatssekretärs Lahr betr. Tagung des Ministerrats der WEU am 30.01.1968, here: Wirtschaftliche Lage in Europa, 31.01.1968, PAAA, B1, vol.332.

47. Gemeinsame deutsch-französische Erklärung vom 16. Februar 1968, in: Europa-Archiv, 23(1968), p.D137. 
to make concessions to the supporters of accession, while the federal chancellery insisted on taking into account French ideas. On 7 March 1968, the federal chancellery therefore prevented the ministry from informing the other governments of the proposed agreement it had drawn up. The chancellery had learned that the French Foreign minister was 'furious, unhappy and concerned" ${ }^{51}$ on account of the voluminous German paper. Shortly before the meeting of the EEC Council of ministers on 8 March, Kiesinger, alarmed, telegraphed Foreign minister Brandt, underlining that an open controversy between the German and French governments had to be prevented. As he affirmed, he had explained to the French ambassador that the German paper was no more than a basis for discussion. ${ }^{52}$ As a result, Brandt cautiously presented the German proposal as an attempt to "create a basis for discussion'.53

Over the following months, however, the Council of ministers failed to agree on the nature of the agreement; neither was there any Franco-German rapprochement on this subject. In an attempt to overcome the stagnation afflicting the European Communities, the West German government put together a comprehensive EEC initiative for the autumn of 1968. This had become yet more urgent following the suppression of the 'Prague Spring' uprising by the Soviet Union on 21 August 1968. In relation to this event, the ministry of economic affairs went so far as to call for a major 'relance européenne'. The further development of the EEC was to be flanked by a trade agreement and institutionalized political cooperation with Great Britain. ${ }^{54}$ The Foreign ministry and the federal chancellery considered the proposal of the ministry of economic affairs as illusory, as there was no chance of France consenting to political cooperation with Great Britain. ${ }^{55}$ There was another reason why the Foreign ministry rejected a 'relance européenne'. The head of subdivision IA, Berndt von Staden, concluded that, following the suppression of the 'Prague

48. On 27 November 1967, Brandt's aide Egon Bahr had noted that it was vital to bring Great Britain and the other EFTA states as close as possible to the EEC, improve economic relations with the EFTA states, prevent a political and economic crisis in Great Britain and establish the 'closest possible ties between the Six and Great Britain (along with the other EFTA states) as the point of departure for the European policy of future French governments'. See Aufzeichnung des Leiters des Planungsstabs im Auswärtigen Amt, Egon Bahr, betr. britischer Beitritt zu den Gemeinschaften; Pressekonferenz de Gaulles vom 27.11.1967, 30.11.1967, PAAA, B150, vol.113, pp.8191-8194, here p.8192.

49. Deutsch-französische Konsultationsbesprechung in Paris, 15.02.1968, AAPD 1968, Doc.59, pp.193-197, here p.195.

50. Vermerk von Staatssekretär Lahr betr. Präzisierung des deutsch-französischen Plans eines 'Arrangements', 29.02.1968, PAAA, B150, vol.120.

51. Gespräch des Bundeskanzlers Kiesinger mit dem französischen Botschafter Seydoux, AAPD 1968, Doc.90, pp.333 f., here p.333.

52. Kiesinger an Brandt, 08.03.1968, PAAA, B1, vol.332.

53. Drahterlass des Ministerialdirigenten Frank, 12.03.1968, AAPD 1968, Doc.93, pp.341-345, here p.341.

54. Schiller an Kiesinger, 04.09.1968, BaK, B136 (Bundeskanzleramt), vol.6415.

55. Vermerk des Staatssekretärs Carstens, 05.09.1968, BaK, B136, vol.6415; Aufzeichnung der Abteilungsleiter II und III, Osterheld und Praß, betr. Europa-Initiative der Bundesregierung, 20.09.1968, BaK, B136, vol.6415. 
Spring' by the Soviet Union, every initiative would seem like a counter-measure. This would once again link the European idea with the East-West conflict, from which it must be kept separate in order to resolve the contradictions in the West German government's European and intra-German policies. ${ }^{56}$

The 'Europeanization' of the German question became clearly apparent here; the idea increasingly dominated in particular in the Foreign ministry. In a keynote speech on European policy on 30 November 1967, Foreign minister Brandt had already pointed out that the solution to the German question depended on "what becomes of the relationship between the two halves of Europe' ${ }^{57}$ For him, over and above the unification of Western Europe, the aim was to bring the countries of Western and Eastern Europe back together 'under changed circumstances, on a new basis'. ${ }^{58}$ The Common market, whose economic potential the East would find impossible to ignore, would play an important role in this.

On 4 October 1967, in a memorandum headed 'Guidelines on Germany's European Policy', Paul Frank, sub-divisional head at the Foreign ministry, identified what specific effects this political conception of intra-German affairs and Ostpolitik would have on the West German government's European policy. According to Frank, the long-term goal of German European policy was to

'reorder pan-European relations, including the problem of Germany, through various forms of economic and political cooperation between Eastern and Western Europe (European peace order) ${ }^{59}$

Thus, before extending cooperation to Eastern Europe, all Western European countries must first be engaged in it. The expansion of the EEC thus constituted 'a necessary step on the way towards pan-European cooperation taking in East and West'. In order to facilitate an active intra-German policy within this framework, it was vital to avoid a situation in which 'the European Economic Community becomes a component of the East-West conflict'. Frank clearly saw the existing European Communities, which would one day develop into a European economic union, as the starting point for German European policy.

In line with this, following the events in Prague, the West German government continued to rely primarily on the EEC; its initiative at the Council of ministers on 29 September 1968 pushed for the conclusion of a trade agreement, a fusion of the Community treaties and the internal development of the EEC. ${ }^{60}$ However, progress was only made when the French government took a more flexible line at the

56. Aufzeichnung des Ministerialdirigenten von Staden über Voraussetzungen für politische Zusammenarbeit in Europa, 03.09.1968, PAAA, B150, vol.134, pp.5894-5904, here p.5903.

57. Die Verantwortung der Deutschen gegenüber Europa. Vortrag auf der Jahrestagung des Kuratoriums der Friedrich-Ebert-Stiftung in Düsseldorf am 30.11.1967, in: W. BRANDT, Außenpolitik, Deutschlandpolitik, Europapolitik. Grundsätzliche Erklärungen während des ersten Jahres im Auswärtigen Amt, Berlin-Verlag, Berlin, 1968, pp.149-164, here p.152.

58. Ibid.

59. Aufzeichnung des Leiters der Unterabteilung IA des Auswärtigen Amts, Paul Frank, betr. Leitlinien für die deutsche Europapolitik, 04.10.1967, PAAA, B1, vol.324. This is also the source of the following quotations. 
meeting on 5 November. The ministers then agreed to ask the Committee of permanent representatives (COREPER) to investigate the potential for an agreement on trade policy. It was now down to COREPER to draw up a meaningful proposal on a trade agreement satisfactory to all concerned.

The main point of contention, the 'accession issues', an increasing burden on the work of the Council, was thus shifted for the time being to the level of the permanent representatives. Over the next few months, the trade agreement was studied intensively in the various working groups established by COREPER. ${ }^{61}$ This alleviated to some degree the increasingly severe paralysis afflicting the Council of ministers as a result of the failure to make progress on the issue of accession: the wretched topic was put on one side for the time being. The positive impact was also evident in the fact that the Netherlands loosened their blockade on technological cooperation, allowing the preparatory work on a common technology policy to be resumed. ${ }^{62}$ The head of the federal chancellery, permanent secretary Karl Carstens, then pointed out to the French ambassador Seydoux that the merit of the trade agreement was that it defused the discussions on the issue of accession. ${ }^{63}$ The leader of the II/1 group at the federal chancellery, Klaus Meyer, summed up the function of the trade agreement more clearly in February 1969. As long as the French stance on the issue of accession remained unchanged,

'it is very much in our interest to prevent a new discussion on the accession issue, in order to avoid putting yet greater strain on the Franco-German relationship and the relations between the Six. The EC Council of ministers is currently keeping the undisguised controversy over accession at arm's length by means of various committees consisting of representatives of the Six, which are examining proposals on a trade policy agreement. This preventative effect is at present the main function of the trade policy agreement. It is in our interest to let this go on as long as possible. ${ }^{64}$

60. Rede des deutschen Bundesministers des Auswärtigen, Willy Brandt, vor dem Ministerrat der Europäischen Gemeinschaften in Brüssel am 27.09.1968, in: Europa-Archiv, 23(1968), pp.D604-609.

61. Gesamtbericht über die Tätigkeit der Europäischen Gemeinschaften 1968, hrsg. von der KOMMISSION der Europäischen Gemeinschaften, Brüssel et al. 1969, p.365; Fernschreiben von Botschafter Sachs, Brüssel (EG), betr. 496. Sitzung des Ausschusses der Ständigen Vertreter Teil 2, hier: Erweiterung und innerer Ausbau der Gemeinschaften, 08.01.1969, BaK, B102, vol. 61708; Gesamtbericht über die Tätigkeit der Europäischen Gemeinschaften 1969, hrsg. von der KOMMISSION der Europäischen Gemeinschaften, Brüssel et al. 1970, p.359.

62. Rat der Europäischen Gemeinschaften, Mitteilungen an die Presse 1865/68, 10.12.1968, PAAA, B20, vol.1518; Gesamtbericht 1968, op.cit., pp.217 f. and p.366.

63. Gespräch des Bundeskanzlers Kiesinger mit dem französischen Botschafter François Seydoux, 30.01.1969, AAPD 1969, Doc.35, pp.123-131, here p.130.

64. Aufzeichnung des Leiters der Gruppe II/1 im Bundeskanzleramt, Klaus Meyer, betr. Entwurf der Erklärung des Komitees für die Vereinigten Staaten von Europa, 20.02.1969, BaK, B136, vol.6410. 


\section{III.2 The WEU detour and the 'Soames affair'}

In its European policy, the West German government put its faith mainly in the European Communities. The Belgian Foreign minister, Pierre Harmel, meanwhile, launched an initiative in October 1968 within the WEU. For the pro-British countries, this had the advantage that Great Britain was already a member. Harmel proposed coordination of the WEU members' foreign and defence policies. A list of topics was to be drawn up for which mandatory consultations were to be prescribed. ${ }^{65}$ When France resisted this initiative, Great Britain and its supporters called for an independent initiative without France. This development put the West German government in a quandary: it wished to avoid opposing France, but was also keen not to appear 'in bondage' to it. ${ }^{66}$ It saw participation in the development of a common stance, to be adopted by the Benelux countries, Great Britain and Italy at the meeting of the WEU council on 6-7 February 1969 in Luxembourg, as a route out of this predicament. At the same time, through this collaboration, the government attempted to influence the common position of the six in such a way as to take the sting out of its anti-French proclivities. Its tightrope act ended in a failure at the Luxembourg council meeting in February 1969, when the British declared themselves willing to consult with the permanent WEU representatives in London before the approaching meeting on the conflict in the Middle East taking place between Great Britain, the US, the USSR and France, the four permanent members of the UN Security Council. ${ }^{67}$ While France rejected this proposal, the general secretary of the WEU invited WEU members to attend a meeting in response to Great Britain's urgent appeals. On 14 February, while dining with the British prime minister Harold Wilson, Kiesinger decided that the West German government would indeed accept the general secretary's invitation. ${ }^{68}$ Because six governments had accepted, the general secretary called the meeting, the $362^{\text {nd }}$ meeting of the council - without France.

Subsequently a fierce dispute flared up over the legality of this meeting. ${ }^{69}$ The French government ultimately grew weary of the discord over the WEU and responded on 19 February, declaring that it would stay away from the meetings until the rule on unanimity was accepted once again by all members. ${ }^{70}$ The West

65. Rede des belgischen Außenministers, Pierre Harmel, vor der Organisation europäischer Journalisten in Val Duchesse am 03.10.1968 (Auszug), in: Europa-Archiv, 23(1968), pp.D609-612. On the Harmel proposals and the discussion about them in the WEU, see V. DUJARDIN, The Failed Attempt to Relaunch the WEU and the Issue of the First Enlargement, in: Journal of European Integration History [JEIH], 1(2006), pp.25-41.

66. Außenminister Brandt, z. Zt. Santiago de Chile, an Staatssekretär Duckwitz und Botschaft Paris, 17.10.1968, PAAA, B150, vol.138, pp.7125 f.; Brandt an Kiesinger, 23.10.1968, PAAA, B150, vol.139, pp.7238 f.

67. Runderlass des Staatssekretärs Lahr, z. Zt. Luxemburg, 7.2.1969, AAPD 1969, Doc. 50, pp.165-167.

68. Ministerialdirektor Frank an Bundesminister Brandt und Botschaft London, 14.02.1969, PAAA, B150, vol.146, p.1038.

69. Aufzeichnung des Ministerialdirektors Frank betr. WEU, 21.02.1969, PAAA, B1, vol.327.

70. AAPD 1969, p.216, footnote 4. 
German government continued to take part in the meetings, but adopted a mediating role. As long as France refused to attend the WEU meetings, Germany prevented the WEU from making substantial decisions by instructing its representative to agree only to those not injurious to French interests. ${ }^{71}$ Above all, the Germans were convinced that the coordination of foreign policy to which its partners aspired was pointless without France. ${ }^{72}$ It thus attempted to cautiously stop the existing approaches. ${ }^{73}$

Kiesinger's decision that the West German government would attend the WEU meeting on which Great Britain was so keen can only be understood in the context of the events surrounding Wilson's visit. Wilson had informed Kiesinger of de Gaulle's offer, made to the British ambassador Christopher Soames on 4 February, to discuss the future of Europe at a bilateral level (the 'Soames affair') ${ }^{74}$ Kiesinger was put out that the French had failed to inform him of this far-reaching decision, having done his best to promote Franco-German relations since he had become chancellor. Kiesinger, moreover, saw de Gaulle's actions as a subject for the consultations between Paris and Bonn enshrined in treaty, which would at least have required that Bonn be informed. ${ }^{75}$

Kiesinger had to wait until the Franco-German consultations of 13-14 March 1969 to learn from de Gaulle what he had said to the British ambassador. De Gaulle outlined to Kiesinger his well-known vision of a 'Europe européenne' independent of the US. ${ }^{76}$ In the closing session, de Gaulle underlined that France wished to consider Europe's future prospects jointly with Germany. The West German government thus assumed that de Gaulle wished to discuss with the Germans those matters which he had not managed to talk about with the British and geared itself towards comprehensive Franco-German consultations on the future shape of Europe.

In this situation, in which the future of European unification seemed open once again, the permanent secretary at the ministry of economic affairs, Klaus von Dohnanyi (SPD), saw an opportunity to introduce again the proposals his ministry

71. Drahterlass des Staatssekretärs Duckwitz an die Botschaft in London betr. WEU/Weiterarbeit des Rats ohne französische Teilnahme, 25.03.1969, BaK, B136, vol.6926.

72. Aufzeichnung des Ministerialdirigenten von Staden, 05.05.1969, AAPD 1969, Doc.143, pp.539-544, here pp.540 f.

73. Aufzeichnung der Gruppe II/1 des Bundeskanzleramts betr. WEU, hier: Ratssitzung am 26. März 1969, 26.03.1969, BaK, B136, vol.6926. Compare Drahterlass des Staatssekretärs Duckwitz an die Botschaft in London betr. WEU/Weiterarbeit des Rats ohne französische Teilnahme, 25.03.1969, BaK, B136, vol.6926; Carstens an Duckwitz, 05.09.1969, BaK, B136, vol.6926; Duckwitz an Carstens, 10.09.1969, BaK, B136, vol.6926. This contradicts the recently made claim that the French policy of obstruction did not prevent progress being made in the consultative political talks. See M. PINE, British Personal Diplomacy and Public Policy: The Soames Affair, in: JEIH, 2(2004), pp.59-76., here pp.75 f.

74. On the 'Soames-Affäre' see M. PINE, op.cit.

75. Gespräch des Bundeskanzlers Kiesinger mit dem französischen Außenminister Debré, 10.03.1969, ACDP, Nachlass Kiesinger, vol.290.

76. Gespräch des Bundeskanzlers Kiesinger mit Staatspräsident de Gaulle in Paris, 13.03.1969, AAPD 1969, Doc.99, pp.367-377, here p.371. 
had made in autumn 1968. In a letter to Foreign minister Brandt, Dohnanyi put forward a modified plan. Britain's application for membership would be upheld but discussed no further for the time being. The EEC would enter jointly a free trade area. In parallel, the Fouchet Plan, involving France, Great Britain, Italy and West Germany, the four most important countries in defence matters would be realized. ${ }^{77}$

Head of department Paul Frank gave his view on these proposals. He believed it would be a mistake for Germany to suggest refraining from discussing accession. However, if France, as expected, went public with new ideas, the debate on accession would automatically be pushed into the background. Creating a free trade area with the EEC as a member would entail significant difficulties. First, it was as yet unclear how the agricultural commodities market could be regulated. Second, Great Britain would certainly not be "content with a "back-row seat" within European economic cooperation'. ${ }^{78}$ Frank was most critical of Dohnanyi's proposals on political cooperation. This, he felt, must not be restricted to the four large countries. The subordination of the small powers must be avoided. Frank justified his attitude with reference to the historic role of Germany within Europe:

'Germany has shown anything but a deft touch within the concert of European power politics, as evident on numerous occasions. The Federal Republic has to grow into the smaller suit, in terms of power politics, which the Second World War and everything that preceded it has left it with. Germany's concept of Europe cannot be inspired by the desire to see it once again playing a role in European power politics [...]. Germany should quite consciously base its approach on the interests of the small European countries and make their concerns its own. The Federal Republic still has a long way to go before the German question is finally resolved. It will be dependent on the support of all European states, particularly the small neutral ones'. ${ }^{79}$

If one's approach was anchored in the imperatives of German policy and the goal of a Pan-European peace order, Frank went on, one must make West Germany's European policy as broadly based as possible. The political cooperation between all Western European states could therefore be sensibly organized within the framework of the Council of Europe.

In order to counter French conceptions with German ideas, the Foreign ministry established a working group in which the ministry of economic affairs also took part. On the basis of Paul Frank's reflections, this group was to examine a tripartite plan for the future of Europe providing for the development of the internal structures of the EEC, a free trade area admitting non-member states and the Council of Europe as a forum for political cooperation. ${ }^{80}$

77. Staatssekretär von Dohnanyi (Bundesministerium für Wirtschaft) an Außenminister Brandt, 26.03.1969, PAAA, B1, vol.327.

78. Vermerk von Ministerialdirektor Paul Frank betr. Stellungnahme zum Vermerk von Staatssekretär von Dohnanyi vom 26. März 1969 über die Europa-Politik, 09.04.1969, PAAA, B1, vol.327.

79. Ibid.; underlined in the original.

80. Vermerk von Ministerialdirigent von Staden betr. Vorbereitung der deutsch-französischen Konsultation am 9. Mai 1969, 27.03.1969, PAAA, B20, vol.1436. 
To the surprise of the West German government, de Gaulle resigned as president in late April 1969 after the failure of a referendum on regional reform. After his departure, it was clear that first a new government had to be elected in France and that any French initiative in terms of European policy was shelved. The plans previously drawn up by the German Foreign ministry, which had begun to review European policy and its conceptual underpinnings only because of the pressure exerted by French reflections on the future of European unification, had thus become obsolete. Rather than pressing ahead with work on the conceptual framework and developing a clear German stance, the Foreign ministry too suspended its work on new plans for Europe. It wished to wait and see how the situation in France panned out, after which it could respond to the new French ideas. ${ }^{81}$

\section{Election campaign (April 1969-September 1969)}

After de Gaulle had resigned in April 1969, the differences of opinion between Kiesinger and Brandt over the best route to the unification of Europe became clearer once again. This was, first of all, because of the more flexible stance of the new French government on the issue of accession and, second, because the election campaign for the parliamentary elections due in September 1969 was now underway.

Kiesinger was first to go on the offensive, publishing a programmatic article dealing with European policy in the journal Politisch-Soziale Korrespondenz, close to the CDU/CSU, on 6 May 1969, followed one month later by a piece in the journal Die europäische Gemeinschaft. In the light of the 'ultimate goal of political union' Kiesinger called for a differentiated approach to European integration, because political union did not chime with the wishes of all those countries interested in closer links with the EC. It was therefore necessary to create a Europe,

'at the core of which the idea of the economic community with the option of a political community in future remains in place and is strengthened, and around which a solution can be found in terms of economic organization which enables the other countries to participate in the economic benefits of such a Europe'. ${ }^{82}$

Willy Brandt publicly advocated an alternative path in order to forge ahead with the unification of Western Europe. At the meeting of the WEU Council of ministers on 5 June 1969, Brandt suggested a summit conference of the seven before the end of the year. Economic and political unification, he asserted, did not necessarily have to tally; the seven WEU members would, however, clearly have to be involved

81. Vermerk des Abteilungsleiters E des Bundesministeriums für Wirtschaft, Jentsch, für Staatssekretär von Dohnanyi, 30.04.1969, BaK, B102, vol.130568.

82. K.G. KIESINGER, Grundprobleme der deutschen Politik, in: Politisch-Soziale Korrespondenz, 6. Mai 1969, p.4; K.G. KIESINGER, Endziel Politische Union, in: Die Europäische Gemeinschaft, 1. Juni 1969 , p.7. 
in both. It would therefore make sense for the seven heads of government and Foreign ministers to meet. ${ }^{83}$ This meeting should take the form of an ad hoc conference, take place independently of the EEC and WEU and 'lay down the baselines for further steps towards the unification of Europe'. ${ }^{84}$ This could, Brandt argued, resolve the open crisis in the WEU and the concealed crisis in the EEC.

On 12 June, in a memorandum to the federal chancellery, Günther Harkort, permanent secretary at the Foreign ministry, gave his views on the problems the chancellor feared would be raised if too many new countries joined. In contrast to Kiesinger, Harkort felt that integration was likely to be deepened and extended as a result of admitting new members. Removing the various obstacles to progress on the issue of accession might trigger an integrative momentum 'which might inspire the governments to find the political will necessary to develop common policies and strengthen the institutions'. ${ }^{85}$ The necessary momentum was unlikely to develop if Great Britain alone joined. Moreover, it was crucial to bear in mind that the government of West Germany had always gone out of its way to take the needs of the smaller European states into account, for good reason. Particularly in the light of West Germany's special predicament and with an eye on the future development of a Pan-European peace order, the 'principle of equality' was of key importance. Any attempt to prevent the smaller countries from joining might

'be interpreted [by them] as a sign that West Germany was pursuing a new power politics $[\ldots]$ and would inevitably have negative consequences for other German interests within European politics as a whole'.

A few days later, Brandt tried to coax a declaration of intent on enlargement out of the new French government, but he was unsuccessful. ${ }^{86}$ Kiesinger, meanwhile, tried to determine how his plans were being received abroad. Positive signals, as could be expected, came primarily from the neutral states, which were in any case barred from participating in a political union but which had a major interest in close economic links with the European Communities. ${ }^{87}$ All the other potential member states feared being relegated to the economic margins. ${ }^{88}$ Despite these negative prospects, Kiesinger stuck to his guns: his fears that the Community might be enlarged too quickly and extensively without further strengthening its political identity received fresh impetus during his visit to the US in August 1969. After his

83. Rede Brandts auf der WEU-Ministerratstagung am 05.06.1969 in Brüssel, AAPD 1969, p.693, footnote 2 .

84. Entwurf einer Aufzeichnung des Referats IA2 betr. Unterlage für die bilateralen Kontakte des Herrn Bundesministers des Auswärtigen zur Vorbereitung einer Gipfelkonferenz der Sieben; hier: Vorschläge für die Argumentation und das Verfahren, 19.06.1969, PAAA, B1, vol.334.

85. Günther Harkort an Karl Carstens, 12.06.1969, BaK, B136, vol.7883. This is also the source of the following quotations.

86. Gespräch des Bundesministers Brandt mit Staatspräsident Pompidou in Paris, 04.07.1969, AAPD 1969, Doc.221, pp.774-780, here p.777.

87. Gespräch des Bundeskanzlers Kiesinger mit dem schwedischen Ministerpräsidenten Erlander in Bonn, 17.04.1969, AAPD 1969, Doc.128, pp.493-498, here p.495.

88. A. SCHUTZSACK, Schlägt die Tür vor Skandinavien zu? Mißtrauen gegen 'Rangordnung' bei künftigen Beitrittsverhandlungen zur EWG, in: Die Welt, 13.06.1969, p.2. 
talks with president Richard Nixon, Kiesinger was more convinced than ever that the US would pull its forces out of Europe within the next ten years and that the Europeans, without a common foreign and security policy, would be unable to fill the resulting vacuum. ${ }^{89}$

Kiesinger thus went into the crucial talks with French president Georges Pompidou on 8-9 September 1969 determined to tackle these issues. The latter, however, expressed serious doubts about Kiesinger's ideas. According to Pompidou, there was very little chance the partner governments might embrace Kiesinger's proposal. Pompidou also made it clear that his priority was to bolster the economic development of both France and Europe. ${ }^{90}$

The grand coalition was thus no longer able to agree on a common goal with respect to European policy. It was left to the social-liberal coalition to implement the decision to open accession negotiations at the summit conference of the EEC countries in the Hague in December 1969. As a counter-move, France was given the assurance that the current financing of the EEC's agricultural policy would be maintained. ${ }^{91}$

\section{Conclusion}

The attitude of the grand coalition government towards British accession was ambivalent. It developed its mediating role on the basis of the coalition partners' desire to avoid confrontation with the French government, with which it had just managed to re-establish a good relationship, and to prevent a crisis in the EEC . The West German government performed this task by putting forward numerous compromise proposals, particularly in the second half of 1967 , by proposing a 'trade agreement' from February 1968 and by mediating within the framework of the WEU.

However, this role adopted by the West German government concealed differing concepts and interests. The Foreign ministry supported enlargement not only for economic reasons but also because it believed that unifying Western Europe in the most comprehensive possible manner was a prerequisite for eventually overcoming the Eastern and Western Blocs. The federal chancellery, meanwhile, felt that enlarging the EEC by admitting Great Britain and the other applicants might put at risk the goal of a Western European political union with a common foreign and

89. Les cauchemars du chancelier Kiesinger, afp-Meldungen Nr.203-205, Krefeld, 03.09.1969, PAAA, Nachlass von Braun, vol.35; Gespräch des Bundeskanzlers Kiesinger mit dem Oberbefehlshaber der Alliierten Streitkräfte in Europa, Goodpaster, 28.08.1969, AAPD 1969, Doc.271, pp.939-941, here p.940.

90. Gespräch des Bundeskanzlers Kiesinger mit Staatspräsident Pompidou in Bonn, 08.09.1969, AAPD 1969, Doc.279, pp.962-973, here pp.964 f.

91. C. HIEPEL, In search of the Greatest Common Denominator. Germany and the Hague Summit Conference 1969, in: JEIH, 2(2003), pp.63-81; C. GERMOND, H. TÜRK, op.cit., pp.73-79. 
defence policy. The chancellery's efforts thus aimed primarily at initiating political cooperation between the Six. The main aim of the ministry of economic affairs was to deepen economic integration in advance of the accession of the new applicants; it saw a fusion of the treaties as the best chance of achieving this. The insistence of the ministry of economic affairs that the West German government play a more active role in European politics is also striking. Here, it was outmanoeuvred by the Foreign ministry in particular. The latter was alert to the danger that the West German government might then pass over the wishes and interests of some countries, upon whose support West Germany depended with regard to both intra-German policies and Ostpolitik.

For Willy Brandt and the Foreign ministry, the fact that plans to get political cooperation off the ground and fuse the communities came to nothing confirmed their analysis, which held that only the accession of Great Britain could create the momentum necessary to overcome the stagnation afflicting European policy. As chancellor, Brandt remained convinced of this.

On the basis of the present study, we need to re-interpret Germany's role with respect to British accession. The German government was very quick to declare itself intermediary in relation to this issue, justifying this with reference to foreign policy. Adopting this position not only had the advantage of arousing in the other countries the least possible amount of irritation. It also seems understandable for internal reasons. By taking this approach, it proved possible to disregard the differences of opinion on European policy and inconsistency of goals within the German government. Time and again, however, the differing viewpoints on British accession came to the fore, hampering West Germany's self-appointed role as intermediary. 